\title{
Performance: An Approach to Strengthening Interdisciplinarity in Women's Studies and Gender Studies
}

\section{Authors}

Ann M. Shanahan, Prudence A. Moylan, Betsy Jones Hemenway, Bren Ortega Murphy, Jacqueline Long, Susan Grossman, Hector Garcia, and Mary Dominiak 
The decision by colleagues in the Gender Research Seminar at Loyola University Chicago to perform María Irene Fornés's Fefu and Her Friends in 2011-12 was a risk that proved transformative. More than we could foresee at the time, the affective knowledge gained through this experiment generated new approaches to our lives and work in research, teaching, and service. Since few of us had a background in performance, we undertook the project based on a set of interests arising from our ongoing research on gender, but without a shared theoretical framework to approach performance as research per se. Ultimately, however, our work together revealed the unique value of performance as an embodied research methodology, even, and perhaps especially, for subjects other than theatre and performance studies, particularly interdisciplinary fields such as women's studies and gender studies. Performing gendered roles in the play deepened our understanding of the performance of gender in our ordinary life and work. We reaffirmed our feminist principles on the importance of including the particulars of embodiment and everyday processes in knowledge creation. We recognized that interdisciplinary collaboration is based in relationships, affectivity, as well as in different frameworks of knowledge. We became more confident about asserting the pedagogical importance of engaging both affect and concepts, and of using performance as a method for achieving this goal. We became more willing to challenge or stretch normative academic expectations of knowledge creation and evaluation. In this collectively written essay, we share the details of our project using performance as research with participants from fields across our university, so that others might consider similar sorts of work to enhance interdisciplinary relationships and spur new forms of embodied research, pedagogy, and community engagement.

\section{The Gender Research Seminar}

The Gender Research Seminar, begun in 2007, is a group of faculty from across the university with research and teaching interests in women's studies and gender studies. Each year the Seminar shares material on a particular subject related to gender, meets to discuss that material each month, and develops programming-lectures, readings, and other events - to promote and further research around it. In 2011-12 the yearlong theme was 
"Gender and Performance," with a focus on the performance of the play Fefu and Her Friends in a mansion on campus. The cast and artistic staff was comprised of nine members of the Seminar, faculty representatives from several departments in the College of Arts and Sciences: Jacqueline Long, Associate Professor of Classical Studies (now Associate Dean of the College of Arts and Sciences); Betsy Jones Hemenway, Director of Women's Studies and Gender Studies (WSGS) with an appointment in History; Prudence Moylan, Professor of History; Héctor García, Senior Lecturer in Modern Languages and Literatures; Ann M. Shanahan, Associate Professor of Theatre; from the School of Communication: Bren Ortega Murphy, Professor of Communication; Susan Grossman, Professor (currently Interim Dean) of the School of Social Work; Mary Dominiak, Assistant Professor, School of Nursing (now retired); and Janet Sisler, Director of the Gannon Center for Women and Leadership.

\section{The Play}

Cuban-American playwright María Irene Fornés's Fefu and Her Friends is an early feminist experiment in alternative forms of dramatic storytelling. ${ }^{1}$ Set in the 1930 s in the country house of Stephanie Beckman ("Fefu" for short), the play concerns a group of female educators who meet to plan a fundraiser connected to an unspecified element of education. Over the course of the afternoon, complex relationships between the women emerge, leading to an ending with deeply resonant implications about the women's relationships to each other and to the larger culture. Fornés employs revisionist alternatives to Aristotelean plot structure and non-linear storytelling. The audience is provided with little more exposition than a fly on the wall in the parlor of Fefu's house; they gather information through experience. In the second act, the single-sided vantage point of audience/actor dynamic is broken and the audience moves around the space to watch scenes in different locations in a different order. This breaks traditional linearity and cause and effect progression of story, and reinforces themes in the content of the play surrounding the non-linear ways we receive information and affect one another. 


\section{The Site}

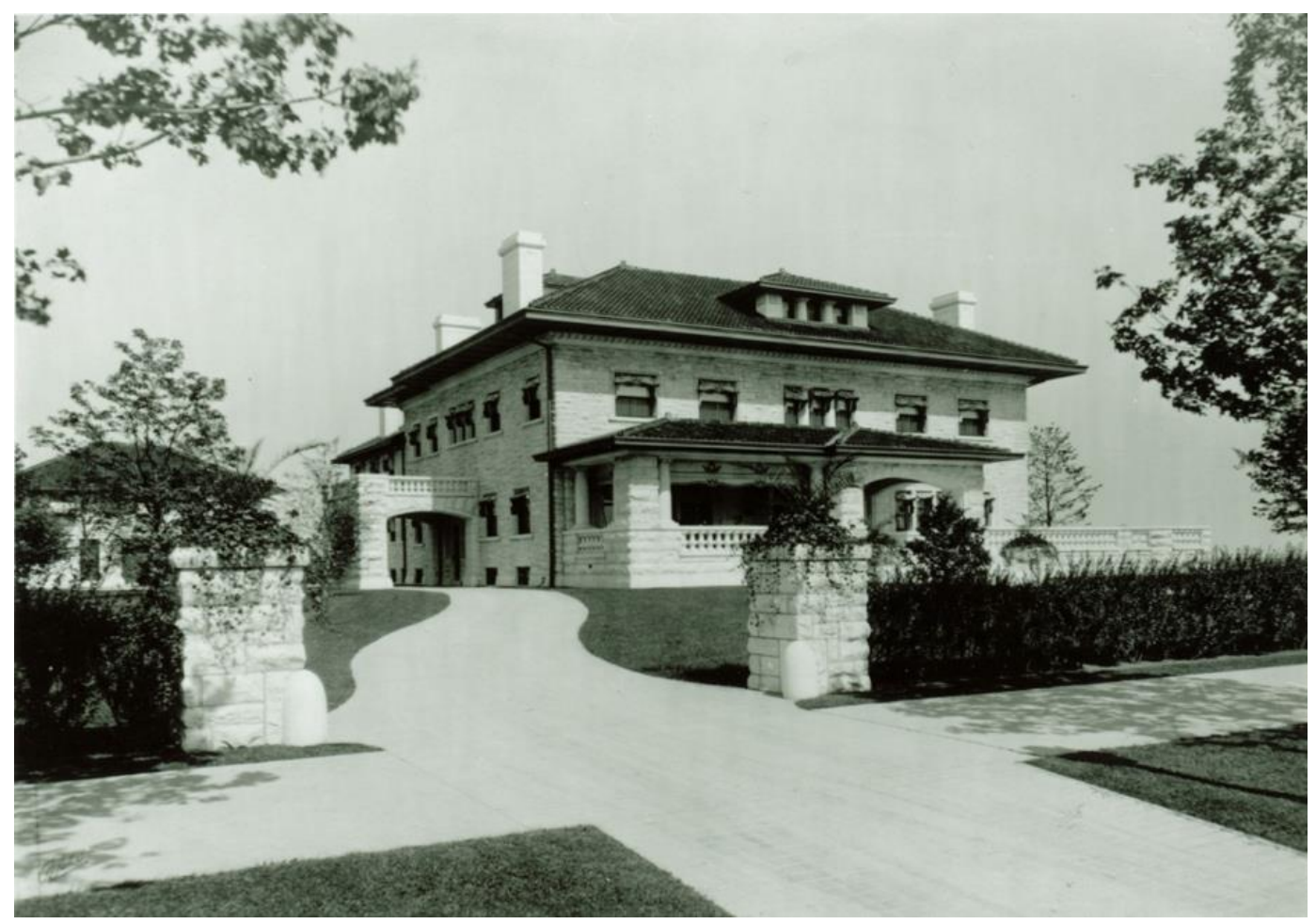

Figure 1. Piper Hall in the 1950s, current home to the Gannon Center for Women and Leadership. (Photo courtesy of the Women and Leadership Archives, Loyola University Chicago.)

The specific features and history of Piper Hall, the site of our project, were integral to this research experiment. Not only did this setting allow for the range of locations called for in the fiction of the play, but as it housed the WSGS Program and the Ann Ida Gannon, BVM, Center for Women and Leadership, the play resonated richly in these environs. A white stone mansion in the early Arts and Crafts style, the house was designed in large part by its first female occupant, Cassie Wheeler, in 1909. In its history, the house was a domestic home to Albert and Cassie Wheeler, and then to Albert and Bessie Johnson, who purchased the home in 1916. In 1934, the house was purchased by Mundelein College, a Catholic women's college founded in 1930 by the Sisters of Charity of the Blessed Virgin Mary (BVM). The building served as the college library until the 1960s, then briefly as a student union and home to various academic programs in the 1970s and 1980s. After the affiliation of Mundelein College with Loyola University in 1991, Piper Hall was neglected 
until the early 2000s, when the BVMs raised funds necessary to restore the building to its original condition as a domestic space on the first floor. The second floor was converted into offices, classrooms, and seminar rooms, and the third floor to the Women and Leadership Archives. When we performed the play in 2012, Piper Hall was also home to the WSGS Program, which was founded at Loyola in 1979, the first women's studies program at a Jesuit university. The date of the play's setting in the 1930s and time of writing in the 1970s are significant in relation to women's education at our institution, themes of the play and pursuits of the Gender Research Seminar, as well as some of our personal histories. As our reflections below attest, the convergence of these historical details in the space and the play figures large in the outcomes of our performance-based research in the mansion.

\section{Project Background and Context}

We decided to perform the play initially based on a set of curiosities and hunches, rather than a focussed, coherent theoretical query or dedicated performance methodology. Only two participants had expertise and practice in theatre or performance studies. Our different scholarly and personal backgrounds and interests gave us each different reasons

to participate. Over several years before performing Fefu, the group had used performance projects in conjunction with our study of interdisciplinary topics related to women and gender. For example, we had used Euripides' The Trojan Women as a focal text when our theme was "Gender and Violence," we used Margaret Edson's Wit when focusing on "Women and Health" and performed a reading of the play in a culminating forum that year. As the group gathered over several years on Saturdays in Piper Hall, a regular member and theatre director, Ann Shanahan, was increasingly reminded of the gathering of friends and teachers in Fornés's play, having directed it twice before. ${ }^{2}$ She suggested we consider staging a full production of it. As the group's conversations around education and feminism deepened, and application of performance in the Seminar increased, the connections between the group's activities, and the play's themes became ever more rich. When we all agreed to the project, it was based largely on instinct; we sensed there was something to be unearthed in the series of resonances between the play and our work, work spaces, and 
personal histories - interplay between art and life. As we discuss more fully later in this essay, our lack of shared coherent theoretical framework in performance at the outset turned out to be an unforeseen gift. Our newness to the process allowed us to learn a great deal about performance as a research method, since we came to it free of assumptions and with fresh eyes.

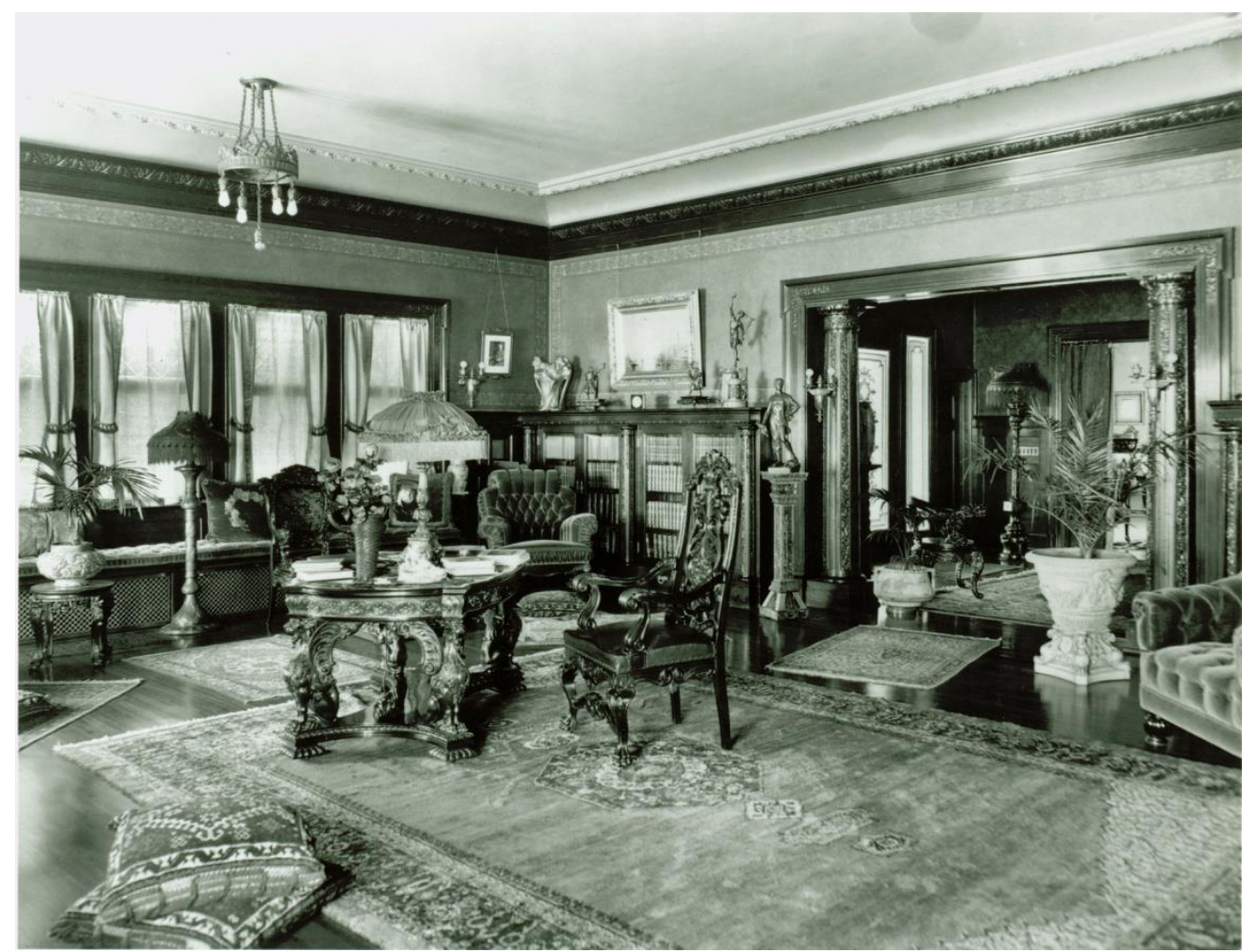

Figure 2. Piper Hall interior in the 1920s. (Photo courtesy of the Women and Leadership Archives, Loyola University Chicago.)

Our shared intention at the outset of the project was to explore interdisciplinarity, embodied through performance. Our work in the WSGS Program and Gender Research Seminar was inherently interdisciplinary because all of us had faculty appointments in separate disciplinary departments at the university. We thought that doing a performance project would help us to understand more fully how to name and claim our collaborative work, which was interpreted in the university as subordinate and marginal to our disciplinary status. Furthermore, we were intrigued by the potential for embodied, collective dramaturgy that the project promised. As scholars in fields intersecting with a 
range of subjects in the play, we were excited to explore how we could collaborate in our analysis of the play in rehearsal, while simultaneously inhabiting the roles.

In addition, we were eager to explore performance-based aspects of feminist pedagogy, gender studies, and affect theory, although the shared theoretical grounding for these came after we had closed the play. Our experience was illuminated and theorized more fully in the following months as we read selected works of Judith Butler, Eve Sedgwick, and other scholars who added new dimensions to our understandings of feminist theory and our work on the performance. ${ }^{3}$ Judith Butler challenges the foundations of feminism when she argues that gender is not a stable identity but a performative practice. ${ }^{4}$ Yet she also argues that gender as performative practice opens new political relationships as it reveals the truth that gender is a political and discursive disciplinary practice, not an interior reality: gender norms are a means to impose social, political, and economic discipline. Embodying our characters required a performative practice of gender as scripted by Fornés, and this led to reflection on our individual performative practice of gender-as scholars, colleagues, and friends. Eve Kosofsky Sedgwick explores embodiment in a different way in her 2002 collection of essays, Touching Feeling. She develops theories of affect through her own forced awareness of body as a cancer diagnosis and treatment brought her into direct engagement with mortality. These essays gave us new confidence in the value of including the body as the foundation of learning that is both non-hierarchical and non-dualistic. Sedgwick describes her work as "a project to explore promising tools and techniques for nondualistic thought and pedagogy." ${ }_{5}$ She writes that her work over the ten years of creating Touching Feeling became more collaborative through shared editorial projects, more personal in her cancer diary, even nonlinguistic in textile art. Both theorists clarified our feminist principles on the importance of the body as a source of knowledge through the performative actions of daily life and freed us from the dualistic burden of the gender binary. While these ideas did not inform our inquiry at the outset, our shared research in these subjects permeates our individual reflections in Part II, as well as the processes of writing and editing them.

As this introductory overview suggests, the many meanings of our performance experience and its influence on us have been revealed through ongoing reflective practices, expanding with each Seminar activity since the production. In the following pages we have 
collected our individual reflections on the process as a way of showing how embodied research through performance has the ability to deepen and enrich interdisciplinary research related to gender.

As we have composed this article together, we have encountered a now familiar difficulty: the limits of traditional scholarly modes of dissemination, in this case a scholarly article, to fully express the interdisciplinary, affective richness of our experiences. We realize again how much more seamlessly these layers could be expressed in performance of a play, rather than in linear text, even co-authored by eight people. Thus, inspired by Fornés's experiments in non-traditional structure, we explain our learning process below in three stages which mirror the three acts of the play. In Act I of the play, Fefu's friends gather at her home and begin to plan a performance to raise funds for a transformative educational project. In our Act I, we gather as friends and plan our performance of Fefu and Her Friends, organizing the project logistically and establishing methods and goals. In Act II of Fefu, audience groups move around the house to learn about the lives of the friends in four different scenes which each group sees in a different sequence. In our Act II, we individually reflect on our experience of performance as research through personal essays. In Act III of Fefu, the play ends with a crisis that demands a new approach to the friends' project. Our Act III reveals how the experience performing Fefu became the transformative event that continues to shape our work together.

\section{Act I: Gathering of Friends}

The play opens with Fefu exclaiming "My husband married me to have a constant reminder of how loathsome women are" (7) to Cindy and Christina, two of her guests, as they wait for others to arrive. Later, Fefu declares she would rather be a man. Fefu and her husband play a game where she shoots him (with blanks) and he falls down. After one of Fefu's shots, Christina observes that it is possible to die of fright. Julia, in a wheelchair, arrives, and the others privately mourn her mysterious injury in a hunting accident, when she became partly paralyzed after a deer was shot. Emma arrives, followed by Paula and Sue. In addition to the discussion of the life and death dimensions of gender relations, they joke and lightheartedly catch up, while sharing fears about performance aspects of an event 
they are planning. Sue asks: "Will I have to act?" and Emma reassures her: "It's not acting. It's being. It's springing forth with the powers of the spirit. It's breathing" (23). Cecilia, not known to most of the group, arrives last when others have retired to lunch; she surprises Cindy and Christina as they remove slugs from the rifle, after Julia, alarmed, sees the evidence of a shell on the floor from Fefu's dangerous game earlier that day.

Having decided in spring 2011 to do the play, we applied for and were awarded money from the College of Arts and Sciences Dean's Special Events Fund to pay for production costs. In fall 2011 we agreed a rehearsal schedule would begin in early 2012. Like the characters in the play planning the fundraising presentation, some of our Seminar members were shy, even reluctant, to engage in performance practice to this extent. It came as a shock when our Theatre colleague, Ann, suggested that the rehearsal schedule would require two or three nights a week for eight weeks and more in the week of dress rehearsals. In reflection of our feminist principles, we decided to operate without a singular director, although Ann provided guidance in acting techniques and at times in staging. Likewise, we operated as a collective of dramaturges, taking the lead in conversations according to our areas of expertise. We spent six or nine hours a week together, which involved fun conversations, support for one another's challenges — including family illness and deathas well as homemade foods to sustain us while we worked. Our excitement mingled with fear as we moved from readings to staging, memorization of lines, costume fittings, and final run throughs. We did three performances in all, Friday and Saturday nights and Sunday afternoon on March 23-25, 2012. Three months of intense relationships as both friends and characters ended at the final performance; our reflection on interdisciplinary performance, however, was just beginning.

\section{Act II: Individual Reflections}

The audience moves throughout the house/set to see the characters in four different conversations that reveal the personal context and questions that shape each woman's life. On the lawn, Fefu and Emma talk about sex and gender as Fefu arranges flowers. Emma notes that sex is ever-present but never acknowledged. Fefu reveals a frightening dream then quickly drops the subject and rushes off to find lemonade. In the study, Christina and 
Cindy engage in word play and joke about divorce and love. Christina admits she feels endangered by Fefu's thinking. Cindy confides a dream of running from a young man she thought was going to kill her. Fefu enters and invites everyone to a game of croquet. In a makeshift bedroom, Julia debates with judges she hallucinates; they torture her even though she tries to give them all the right answers. She promises to say her prayer, "Everything on earth is for the human being, which is man" (35). Lamenting that all women on earth have been able to learn this prayer, she asks, "Why can't I?" (35). In the kitchen, Paula has a conversation with Sue about the unfolding stages of a love affair and how the break up affects "the brain, the heart, the body, mutual things, shared things"(38). Sue leaves to bring a bowl of soup to Julia and Cecilia comes into the kitchen. Cecilia suggests that she and Paula rekindle their relationship. Paula expresses her hurt and anger over their breakup just as Fefu appears to suggest a game of croquet.

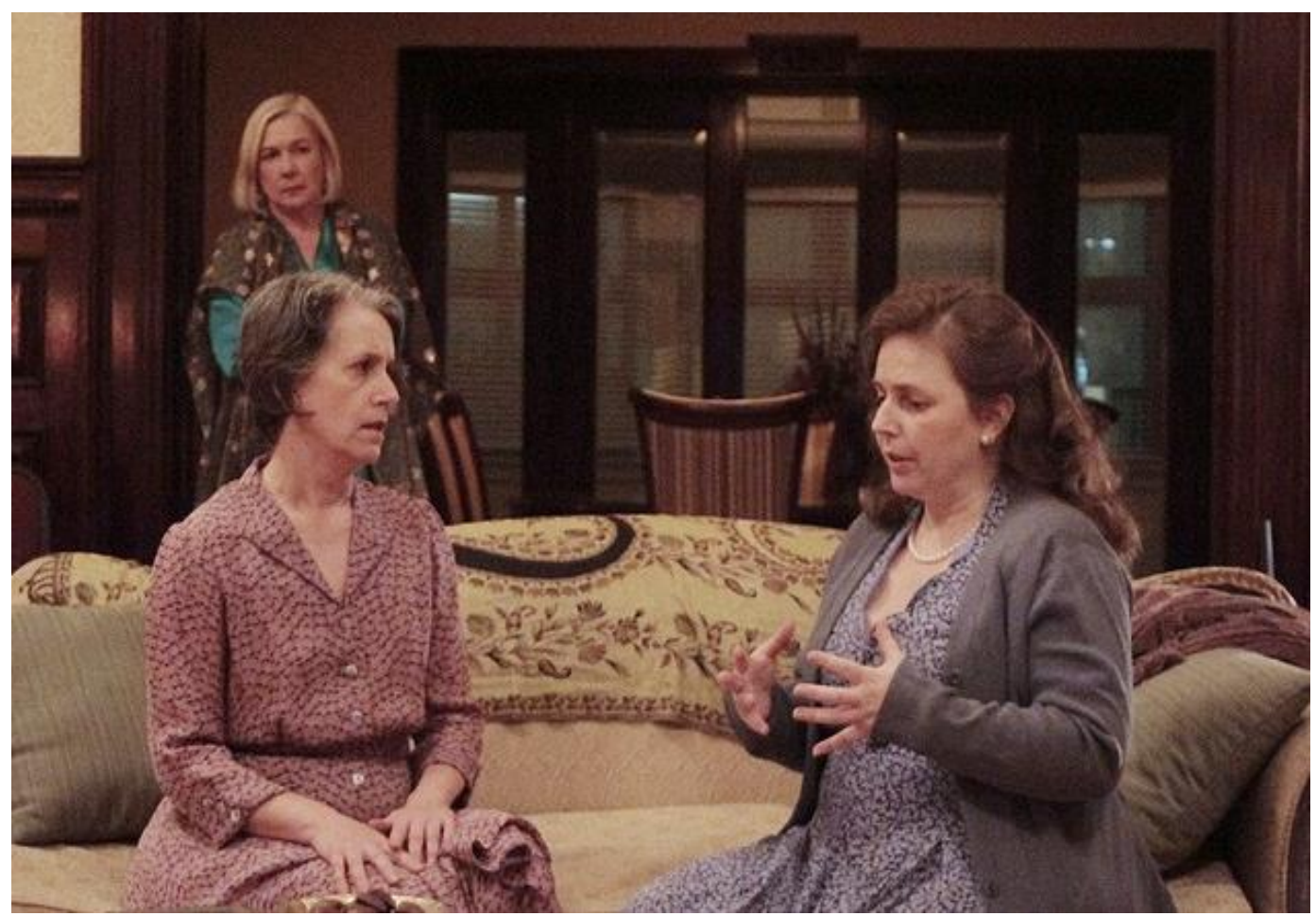

Figure 3. Fefu and Her Friends in the drawing room of the restored Piper Hall. (Photo courtesy of the Department of Fine and Performing Arts, Loyola University Chicago.)

Since our performance project was an exploration of interdisciplinarity, we agreed to each write a short reflection on what we learned about ourselves, our teaching, and our 
research from performing together. The eight personal scholarly narratives that follow demonstrate the ways our understanding of embodied performance in the play expanded into all aspects of our work, including writing itself. The authors were all female members of the cast with the exception of our male Seminar colleague, Héctor García, who took the role of the outside, male viewer in the project. Mirroring the off-stage male presence of Fefu's husband Philip, Héctor served as dramaturge and outside eye for the project; he also videotaped a performance.

\section{Ann M. Shanahan, Associate Professor of Theatre, Department of Fine and Performing Arts}

Because I teach acting, the intersections between this project and my teaching and research are more direct than for many of my fellow cast members. The play offers opportunities to make several connections between acting and living; meta-theatrical references permeate its content. Emma, the most overtly theatrical of the characters, declares "Life is theatre. Theatre is life. If we are showing what life is, can be, we must do theatre" (22). I suggested colleagues in the Seminar perform Fefu and Her Friends because of this connection between art and life, and it is in this interplay that my work has been most impacted by the project.

By far, the dominant effect of the performance project for me has been a deepened connection to my colleagues in the project, the space (and history) of Piper Hall, and my students and fellow faculty who saw the play. When I meet cast members at university functions, the bond between us is palpable; performing this play has enriched the dynamics of our interactions. I experience a different relationship to the environment of Piper Hall; I have taught classes and directed performances there in the past, but entering the space as a character from the 1930s facilitated a new identification with the building, particularly with its history in relation to women. Finally, in performing for my students, I reversed the relationship hierarchy that occurs in my acting classes. I have since realized the feminist implications of this move-I abandoned the position of the observer to become the observed, and in so doing, gave up the professorial position and to become a subject. 
Expanding beyond traditional forms of interaction opened new ways of relating in everyday life, for my colleagues, our work, our spaces, and our students: "If we're showing what life is, can be, we must do theatre"(22). The play itself disrupts many standard forms-linear Aristotelian structure, traditional spatial orientation, actor/audience relationship, cause/effect relationships, and other tenets of Realism. After performing inside the play, I have come to acknowledge how deeply Fornés engages with traditional Realism in order to both break and extend it.

Feminist scholars have critiqued Realism as "a prison house of art for women." Considering the architecture of the proscenium theatre and the apparatus of viewing within it, Jill Dolan, Elin Diamond, and Sue Ellen Case have argued that the privileged position vis-à-vis a fourth wall invokes a male gaze and colludes with other stylistic features to objectify female characters. ${ }^{7}$ A woman's full and authentic expression in performance ultimately forces her to rupture the fourth wall and shift the traditional mimetic relationship of observer/observed. Feminist practitioners have employed a variety of tactics to break out of the box sets, climactic plot structures, and performance styles of this period, rendering Nora Helmer's famous door slam not only a departure from the doll's house of her marriage, but from a style of performance that could not contain her authentic self. ${ }^{8}$

In Fefu, Fornés gives us clear markers of standard Realism and then enlarges them. A famous anecdote relates that Fornés had only read Ibsen's Hedda Gabler before she began writing plays herself. ${ }^{9}$ Scenic parallels between Hedda and Fefu are several; in both, a house is a central symbol. The stage directions for Fefu describe a parlor reminiscent of Ibsen's symbolically encoded box sets, complete with French doors (7). In both, the central female character engages in a game in which she shoots an offstage male; Fefu shoots her husband Philip in the same way Hedda shoots Judge Brack. Both plays concern a female character who is trapped "in the dark," envious of men's freedom. Both plays use the image of autumn leaves as a significant symbol for the decline and ultimate death of a central female character. Both capitalize on the phallic imagery of the guns fired and both conflate creativity with fertility. Likewise, both explore the relationship between the exterior and interior spaces, in a manner that is significant to the Realistic style and theatre in general, particularly for women. The interior space is female, the outside male. Elinor Fuchs writes, "Fornés genders the out-of-doors male in Fefu, she genders the interior, with its depth, 
penetrability, and comfort - its domestic spaces figured as body parts and inner organsfemale." 10 This equation extends to the experience of the spectator in Part II. Fuchs concludes that, as a result "at the level of text, dramaturgy, and reception, the play is embodied"; Fornés aims to expand Realism to include women's bodies. ${ }^{11}$ Fuchs writes:

Not content to merely align her spectators and her actors on facing planes, Fornés now welcomes her audience in the very body of Fefu's house. Like the body and unlike most stage sets the house has depth and scale matched to our own human bodies. But beyond such familiar associations, spectators begin to discover something unfamiliar, the specificity of their own bodies in the theater. ${ }^{12}$

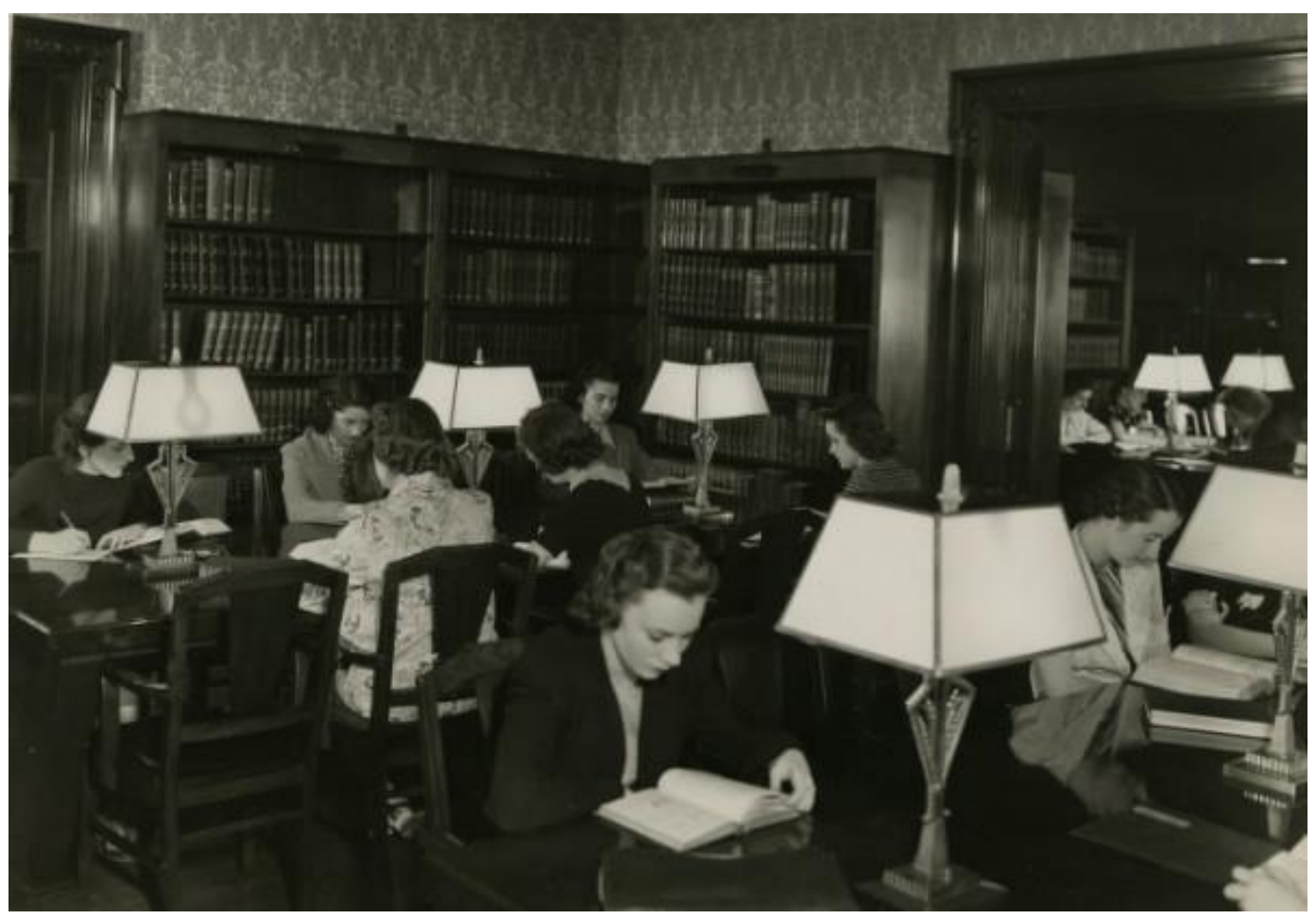

Figure 4. Women in the library of Piper Hall in the 1930s. (Photo courtesy of the Women and Leadership Archives, Loyola University Chicago.)

As Fornés takes the best of Realism and amplifies it, so our project took Fornés's impulses and expanded those. I know I am not alone when I express the uncertainty that arose throughout this project because most of us were not actresses-concerns ranging from logistics to the quality of the art. Colleagues wondered why we had undertaken the play, as it did not seem to relate to any markers set for us in the Academy. I now realize that it 
has been precisely lack of artifice, our realness, in which the profound meaning of this project lies.

This breakdown in boundaries between art and life was intensified by staging in a space with both an actual history and a real function in the present - both domestic and educational - for women. Not only were we made aware of the materiality of female bodies in the house, we were made aware of the bodies which had occupied the site in the past. In addition to enhanced awareness of the women's bodies performing, including my own, I found myself conscious of the woman who designed Piper Hall, and of the women who had occupied the space as a library for Mundelein College. By occupying this site from the point of view of a woman in another time, I dwelt in the house that had held women's lives (and bodies) in the past, and thus encountered them in a different way. ${ }^{13}$

In the years since this experiment I have gone further in using performance projects to break down hierarchies in classrooms and rehearsal halls. For example, I demonstrate the aesthetic principles of Bertolt Brecht while simultaneously performing the feminist pedagogical strategies of bell hooks. ${ }^{14}$ I reconfigure spatial arrangements to skew structures of power and binaries. I am currently in the process of combining these strategies to unpack and dismantle political biases in traditional Realistic acting techniques in relation to categories such as gender, sexuality, race, ethnicity, class, and religion. I am able to explore these strategies with more depth and grace because I inhabited Fornés's related explorations performing Fefu, and particularly because I was able to understand them in greater dimension by analysis through shared, embodied experience with my expert colleagues in WSGS.

\section{Susan Grossman, Professor and Interim Dean, School of Social Work}

In comparison to some of the other fields represented by the women taking part in Fefu, social work is not a discipline per se; rather, it draws from several disciplinesincluding psychology, sociology, political science and economics - to create a body of theory, practice and knowledge oriented towards understanding the person within their environment. Pedagogically, the focus is on context - on understanding the intra, inter, and external factors that, when combined, explain why someone or some system exists as it is. 
To some extent, this framework mirrors Butler's work related to the social construction of gender identity, even if it does not strictly speak to performance as a means of solidifying that identity. ${ }^{15}$ It asks us see the individual as being shaped and ultimately constrained by social, political, and economic forces in the broader environmental context, and the policies and social responses to which these forces give rise. It acknowledges that the individual is an actor in the context of the possible roles he or she has been given and asks us to consider the larger context shaping these roles and responses.

How does this relate to Fefu? On a very concrete level, one can see the interrelationship between person and environment quite clearly in the actual performance of the play. Each character exists as an isolated individual with her attendant personal history, and that story plays out in her interactions with the other characters within the physical space of the house. This is an intellectual understanding of context and interrelationship, but I experienced the same dynamic at an emotional level in the act of performing. I embodied my own character and felt who she was in the context of my interactions with my fellow performers. Similarly, the audiences' understanding occurs both in interaction with that character, and in the interaction between that character and the others in the play. The order in which the audience moved through the house influenced their interpretation and understanding, particularly in Act II, where each scene unfolds simultaneously but is viewed in a different order by the audience, depending on where each member begins and ends. To me, this last point perfectly captures social work's view of the person nested in his or her environment; it also reflects the key principle of practice that requires the practitioner, as a starting point for intervention, to suspend her/his own personal view in order to align with the client's perspective.

I could argue that Fornés was a social worker at heart, and yet reading the subsequent reflections of my co-creators included here I see how they, too, observed their own disciplines in the words we spoke. Gender and power, class and oppression, classical theatre and the arc of a play were all lenses used to understand the characters, their actions and interactions. In understanding how a character was viewed through each specific lens, I could better understand how that particular theoretical perspective framed the world.

In discussing our experience, one question we considered together was how the process of performance affected our teaching. Certainly, teaching requires performance- 
pitch, tone, presentation, all timed in a way to facilitate engagement with students. As a teacher, I have often thought of myself as the performer and my students as the audiencemy teaching has not been a full act of co-creation. Participating in Fefu helped me to see how learning could occur in a different way: I felt myself to be one part of a larger whole that relied on each of us. I was more aware of my fellow performers than I was of the audience; of how we worked together to create meaning and embody Fornés's words. It was a process of creation that was more than the outcome; trusting in the process of each actor, I was less worried that a specific message was "received" by our audience.

The process demanded that I assume a different role; I shed the skin of an academic to embody the part of my character, and my colleagues' ability to assume their roles was dependent on how well I attended to mine. It was a circuitous process-I judged my success according to how much I could relate to my fellow actors in their roles, not as my colleagues. The more effectively I could do this, the deeper my embodiment of my own role, and so we built on our mutual success. Loosening one's hold on a specific identity is an integral part of providing support to clients in the social work profession-an ability essential to good social work practice. It requires putting aside one's own biases and perceptions, accepting those of another, and working together within that shared framework.

I have noticed a subtle shift in my approach to teaching since performing Fefu and Her Friends. I spend less time on factual data in class, and more on encouraging co-creation of meaning with my students. Ultimately, this is more in line with my wish to teach students to be critical thinkers, and I still feel more comfortable in the classroom than on the stage; this may be because of my illusion that I have more control in the classroom context, my comfort with the role of "professor," or my familiarity with both the setting and the role.

\section{Mary Dominiak, Assistant Professor, School of Nursing}

The invitation to participate in the production of Fefu and Her Friends was one that I accepted primarily because of the extremely positive experience that I had after joining the Gender Seminar in 2009. I knew that the production was important to Ann, as well as the others, and I wanted to support her enthusiasm for the project. Thus, my participation 
was not theoretically driven, but based on the friendships that I had developed with an incredible group of women and men. And, it sounded like fun!

My discipline in nursing, along with my career background in healthcare and business, positioned me uniquely among my colleagues — nursing has only within the past twenty-five years been identified as a discipline with its own body of knowledge, rather than as a sidebar of medicine. Hard science and business principles had guided my worldview prior to participating in the project, albeit one that was seen through a feminist lens. The project and the research seminar focused that lens for me.

The play resonated on several levels, particularly the historical tension between men (medicine) and women (nurses), as well as Fornés's references to the tensions between women (more currently, women in medicine versus those in nursing). The vivid imagery within Fefu and Her Friends connected with stereotypical images frequently used to depict nurses as the angel, the sexy nurse, the battle-axe, and the physician's handmaiden. These images are in stark contrast to the reality of nursing and its work, just as within the play, words describing women as loathsome are not validated. The process also facilitated reflection on the dynamics of working in a predominantly female profession, with its benefits and challenges.

The structure of the play aligned with my discipline in its non-linearity. Unlike the biomedical model that dominates our healthcare system, nursing is relationship-based. A nurse sees a person not as a disease to be cured or a tumor to be removed (language, "the gallbladder in Room 205”), but as a physical, social, psychological, and spiritual being.

There were parallels between my discipline and my character. Cecilia was the outsider in the group — scientific discipline made me an "outsider" of sorts. Cecilia both wanted to control the relationship with Paula and was also drawn to Paula's strength. Similarly, in nursing, we want patients to do what is best for them and coach/educate/nudge them in a direction. At the same time, we want them to take charge of their own lives and be less dependent upon others.

For me, Cecilia's discussion at the beginning of Act III gives voice to the struggle within all of us, the desire to be who we are versus the desire to fit in, not to be alone. Thus, we are all actors, balancing when to reveal ourselves and when to hide that which we are afraid to reveal. The experience of participating in the play was an epiphany for me. Being 
somewhat of a perfectionist, I was not only afraid of not looking good, but also of letting the others down. Taking the risk of putting myself on stage was possible because of the support I had from my fellow cast members and crew. I was able to make mistakes without being criticized. I learned that my goal as a performer was to consider the response that I wanted from the other actors. That lesson has impacted my personal and professional relationships.

When considering the question of how this experience affected my teaching and research, I think immediately of my role in the classroom as performance venue. I have always been a strong proponent of experiential learning and incorporate this pedagogy in all of my classes. Reflection and discussion helps students to link their experience with theory. Nevertheless, I have found myself falling back on the more traditional "teacher as performer and students as audience" model when the in-class discussions falter. As I continue to struggle to avoid this choice this semester, I recall Ann's guidance to consider what emotion or response my character wanted to elicit from the others. I am now spending more time in class preparation thinking about what response I want from the students.

Following the performances, the cast discussed the interaction with the audience as a positive experience. I remarked that the event gave students the opportunity to see us differently, that is, as people not the professor. This has allowed me to be more revealing of myself in class which results in more student engagement, and I find that to be rewarding. What was most supportive to me as a scholar was working with colleagues from many disciplines to which I had little exposure; it opened my eyes to a broader definition of interdisciplinarity. I have since created an interdisciplinary course focused on ending childhood obesity that draws from nursing, medicine, sociology, psychology, public health, business, and communications, which has allowed me to partner in research projects with other disciplines. 


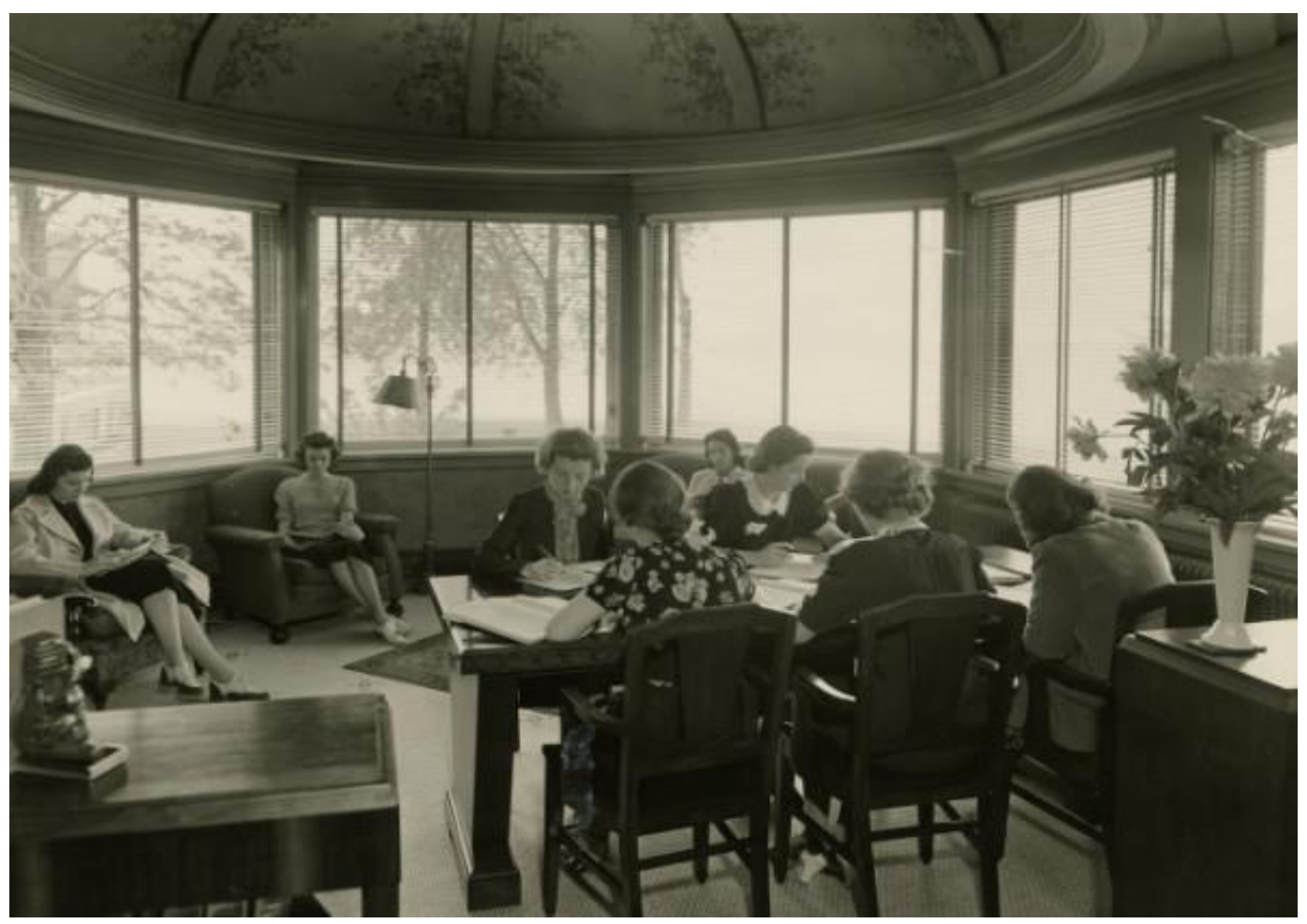

Figure 5. Piper Hall served as the library of Mundelein College in the 1950s. (Photo courtesy of the Women and Leadership Archives, Loyola University Chicago.)

\section{Prudence Moylan, Professor, Department of History}

As a person who was born in 1939, earned a History $\mathrm{PhD}$ in 1975, and performed this play in 2012 on the cusp of retirement, the Fefu project enabled me to achieve a deeper integration of personal and professional life experiences. The mansion setting for our performance of Fefu included the library, a space I loved as an undergraduate at Mundelein College from 1961-1963. In these same years Mundelein undertook a self-study on its future as a college for women. As a research assistant to one of the faculty participants in the study, I had to read and create an executive summary of Betty Friedan's The Feminine Mystique. This was my introduction to feminist theory, even though I was in the second generation of college-educated women in my family. My mother and my aunts could have been the characters in Fefu and Her Friends.

My undergraduate and graduate education included lots of informal "consciousness raising" with women but no formal courses offering a focus on women and gender in history. The first women's studies program began at San Diego State in 1970. As a young 
scholar, I worked with colleagues to pioneer such a program at Mundelein College in 1981. Mundelein became part of Loyola University Chicago in 1991 and I became a Loyola faculty member in History. Even so, I grieved the loss of my home because the Mundelein space no longer belonged to a community of women. In Loyola's Women's Studies program, established in 1979, colleagues recognized and affirmed the Mundelein legacy but they did not share my sense of loss. Performing Fefu in Piper Hall in 2012 reclaimed the place/space, temporarily, for a community of women, and confirmed my understanding of feminist pedagogy as a relational practice - it also provided a catalyst for witnessing how research on gender and peace activism could transcend the gender binary.

I will begin by explaining what I learned from Paula, my character. Paula is a woman from a poor family who attended college with Fefu and her friends, most of whom enjoyed an economically privileged family life. Paula struggles to understand her feelings of loss and to recover her confidence after the breakup of a lesbian relationship. Encountering her former partner among Fefu and her friends provokes Paula's anger. She is unsure of her role in the new education project and bursts into tears after challenging her friends to understand the differences in the lives of poor and rich by contrasting her college experience as a working girl with their freedom to vacation and travel. Paula crosses boundaries of class and heterosexual norms, but she also suffers the emotional pain of uncertainty and continual negotiation. All the characters in Fefu and Her Friends are negotiating social norms as imagined in a 1935 setting, but in reality written in 1977. Women's studies was created as an academic field in 1970 to support challenging gender norms - it was often described as "feminism's academic arm."16 Performance as research, expressed through this play, defined our lives in relation to the narrative arc of women's history.

My own childhood story reveals the origin of a metaphoric tension in my life between conversation and performance. My mother was a playwright, performer, and a high school English teacher. As a child I resented her performances as somehow making her a different person who made my mother disappear. I think now that as a teacher, I feared performance as a loss of identity while conversation allowed me to be myself. Ann concluded our acting workshop with the admonition that in speaking our lines we should always have a clear intent to communicate with another character. This theatrical directive 
suddenly brought conversation and performance together and opened up new approaches to playing the role of teacher.

In the same semester as rehearsing and performing in Fefu I taught an undergraduate course on twentieth century peacemaking. As usual, I developed a very demanding reading list and then despaired of finding a way to engage the students in actually doing the reading. I decided to divide the texts among student groups, who would each make a report to the class. In the mid-term review students noted that attendance was higher than in any of their other classes, because they felt responsible for supporting their peers. Inadvertently, I had asked the students to play their role in creating knowledge just as my colleagues invited me to play a role in Fefu as performance research. Both instances demonstrate the affective, relational conditions of learning. For me this experience brought a deeper understanding of Judith Butler's argument that we learn/know ourselves through performative acts.

In 2012, I was doing research on the women's peace camp at Greenham Common. Ann Pettitt, the initiator of the 1981 women's march from Cardiff, Wales, to Greenham Common in England as a protest against nuclear weapons, was motivated to act politically out of her own experience as a woman. ${ }^{17}$ Sasha Roseneil argues that the women who marched and then camped at Greenham posed the first conscious feminist political challenge: "to disarm patriarchy, to resist and transform relations of male dominance and female subordinations." ${ }^{18}$ Both Pettitt and Roseneil explain the Greenham women's choice to use gender identity as a performative expression of their politics within a binary gender framework. Our exploration of gender as performative in doing the play and in discussions that followed opened my path to escape the binary. Joan Wallach Scott, a notable feminist historian, asserted the usefulness of gender analysis in history. "Gender is one of the recurrent references by which political power has been conceived, legitimated, and criticized. It refers to but also establishes the male/female opposition." ${ }^{19}$ Butler confirms this view of gender and power arguing that the "sedimentation of gender norms [produces] corporeal styles which... appear as a natural configuration of bodies into sexes existing in a binary relation to one another." ${ }^{20}$ Butler goes on to suggest the solution to breaking the gender binary is the proliferation of "cultural configurations of sex and gender." 21 Greenham women began the process of proliferating cultural configurations, but I would 
not have recognized the transformative power of their gender transgressions without my experience of performance as research.

My citizen activism in retirement continues to integrate insights gained through performance as research and the importance of interdisciplinarity in understanding societal challenges. It was perfect timing in my life to have this opportunity to integrate and consolidate memories of my life. I am profoundly grateful for this experience that healed my grieving heart and defined my work as a participation in challenging disciplinary practices of power. My transition to retirement, rather than bringing a loss of identity, has become a continuing daily performative practice of learning through relationships and new forms of civic engagement.

\section{Betsy Jones Hemenway, Director, Women's Studies and Gender Studies; Senior Lecturer, Department of History}

I am somewhat embarrassed to confess that, coming into this project as a historian, I had not often considered the ways in which performance-and especially gendered performance - is embedded in my daily life and work. Of course, I had read and taught much of the feminist scholarship, but this usually had been done in a somewhat detached, intellectual manner. Performing Fefu and inhabiting a character distinct from myself compelled me to reflect on how I perform my gendered self and my relationships with colleagues. We formed a unique scholarly community that explicitly and intuitively created knowledge together, inhabited spaces and crossed spatial boundaries, and contemplated the historical convergences that Fornés alludes to and that we experienced throughout and beyond the project.

The rehearsal and performance process played out a number of tensions in multiple ways. We dealt with the fundamentally physical tension of space, as Piper Hall became both a theatrical and real domestic space, where the characters seemed simultaneously imprisoned, connected with one another as a community of women, and in conflict. The drama unfolds in a non-linear way within a non-traditional theatrical space, another challenge for us in moving, speaking, and timing. The characters advocate for women's

education while falling deeper into despair; the more education they achieve, the more they 
see that they are doomed. As Julia acutely perceives, the act of standing as an independent woman and speaking one's mind produces hallucinations, paralysis, and death. At times, these stark truths are exposed, at others glossed over.

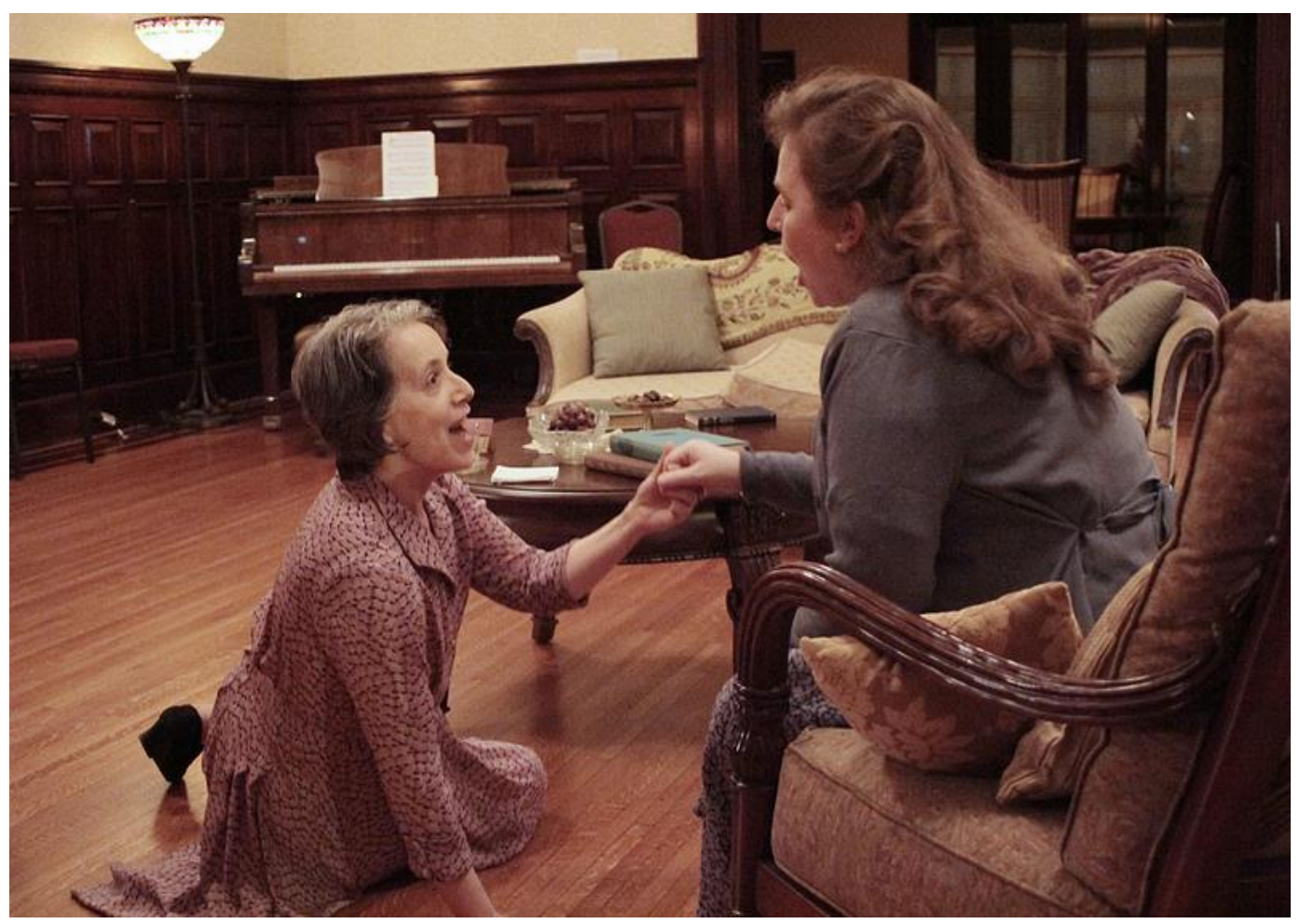

Figure 6. Betsy Jones Hemenway as Christina and Ann M. Shanahan as Cindy sing "Winter Wonderland." (Photo courtesy of the Department of Fine and Performing Arts, Loyola University Chicago.)

For some of us, Piper Hall was our regular work space; then at times it became our performance space, rendering the boundary between daily life and performance more porous. The building's strong link to the history of Mundelein College also created a companionship with the students, faculty, and staff of that institution, whose photographs, papers, and living bodies (including those of our colleagues Prue Moylan and Jan Sisler) were still physically present. Moreover, the drama of the play sometimes spilled over into other aspects of our lives. Our daily existence intersected with rehearsal routines, as personal triumphs, dramas, and challenges entered our common space. There were also moments of interpersonal tension. As Christina, I often found myself becoming angry with 
Fefu's speech and behavior, to the point where I felt compelled to reconcile with my dear colleague and friend Bren Ortega Murphy every evening after rehearsal. Working together deepened our relationships with one another and enabled us to share an openness and intimacy we ordinarily would not have as colleagues. There were certainly moments when we despaired that the situation for women had changed very little since the 1930s. Nevertheless, in our own small way we demonstrated that in 2012 women could combine full intellectual and creative lives with family and other traditionally feminine pursuits.

Such examinations of women's conditions across chronological boundaries occurs in an oblique reference during Act I. When Paula remarks that she enjoyed a talk that Fefu gave at Flossy Crit (1930s slang for Feminist Criticism), Fefu disparages her own presentation, declaring that it was "awful" (a response of self-deprecation that resonated with most of us). When pressed, she says the talk was about aviation, but it turns out that it was about Voltairine de Cleyre, a prominent anarchist and feminist of the late nineteenth and early twentieth centuries and contemporary of Emma Goldman. One of de Cleyre's central concerns was "the question of how women in particular can resist the configuring of their inner lives by the social, political, and economic configurations of an oppressive society," a central theme of the play. ${ }^{22}$

De Cleyre argued that the state was particularly oppressive toward women; it regulated the relationships between men and women, enforcing monogamous marriage that subordinated women, effectively imprisoning them within the home or, more specifically, the marriage bed, where they were compelled to have sex with their husbands and produce children. For de Cleyre, marriage was nothing less than legalized prostitution, or the enslavement of women. Such "sex slavery" was the result of the "mind domination of the Church, and the body domination of the State. ${ }^{23}$ In short, women either had to make their own way in a society that offered few opportunities (as impoverished teachers or prostitutes) or they married men to whom they were required to surrender their entire beings and thus lose any possibility for freedom or self-fulfillment.

While we do not know exactly what Fefu said in her talk, she occupies precisely the position that de Cleyre condemns. She complains that she and her husband Phillip (who resides off-stage) do not share a deep intimacy; indeed, they hate one another. At one moment, Fefu declares that she wants to be a man. She envies men, who can roam outside 
in the fresh air, move, and enjoy their freedom, while she and the other women are inside the dark house, contemplating their imprisonment within society's restrictions. They are psychically saved only by the presence of men, who anesthetize and soothe them, so that they do not have to feel the pain of their existence. Of course, the price of this slavery is high - "the mind and the spirit" (15). And perhaps this is why Fefu denies she ever spoke about Voltairine de Cleyre. To admit to her own entrapment, at least in the first act, is simply too painful. Instead, she playfully shoots her rifle at Phillip and gamely entertains her guests, avoiding acknowledgement of her (presumed) affinity with de Cleyre's views while standing in her (own) husband's home.

The experience of performing Fefu placed us in a position of vulnerability, where we acted out everyday tasks and wrestled with the paradoxes of modern feminism. In crossing the boundaries of theatre and "life," we developed empathy and deeper connections with one another, making our abstract knowledge of women's history and the history of the spaces we inhabited more concrete and embodied. Moreover, in Fornés's play, the words we spoke were linked simultaneously to a deeper historical tradition of anarchism and feminism, the inner struggles of the characters, and our own challenges in creating meaningful lives for ourselves. Theatre and performance, therefore, has become for us a way to cross boundaries between history, daily practice, personal struggle, and growth.

\section{Jacqueline Long, Associate Professor, Classical Studies; Associate Dean, College of Arts and Sciences}

Much of Classical Studies begins from texts that work like scrims through which whole words appear in flattened focus. Study brings them into depth, life and meaning. In preparing my role in Fefu and Her Friends, I began with much the same close reading I would use to investigate a problem in a Classical text. What affect knits the words and actions of the script together into plausible coherency? What understandings are implied? What cultural habits inform references and interactions? Acting gave me new challenges of expressing my readings, but methodologically our dramaturgical collaboration started from ground familiar to me. 


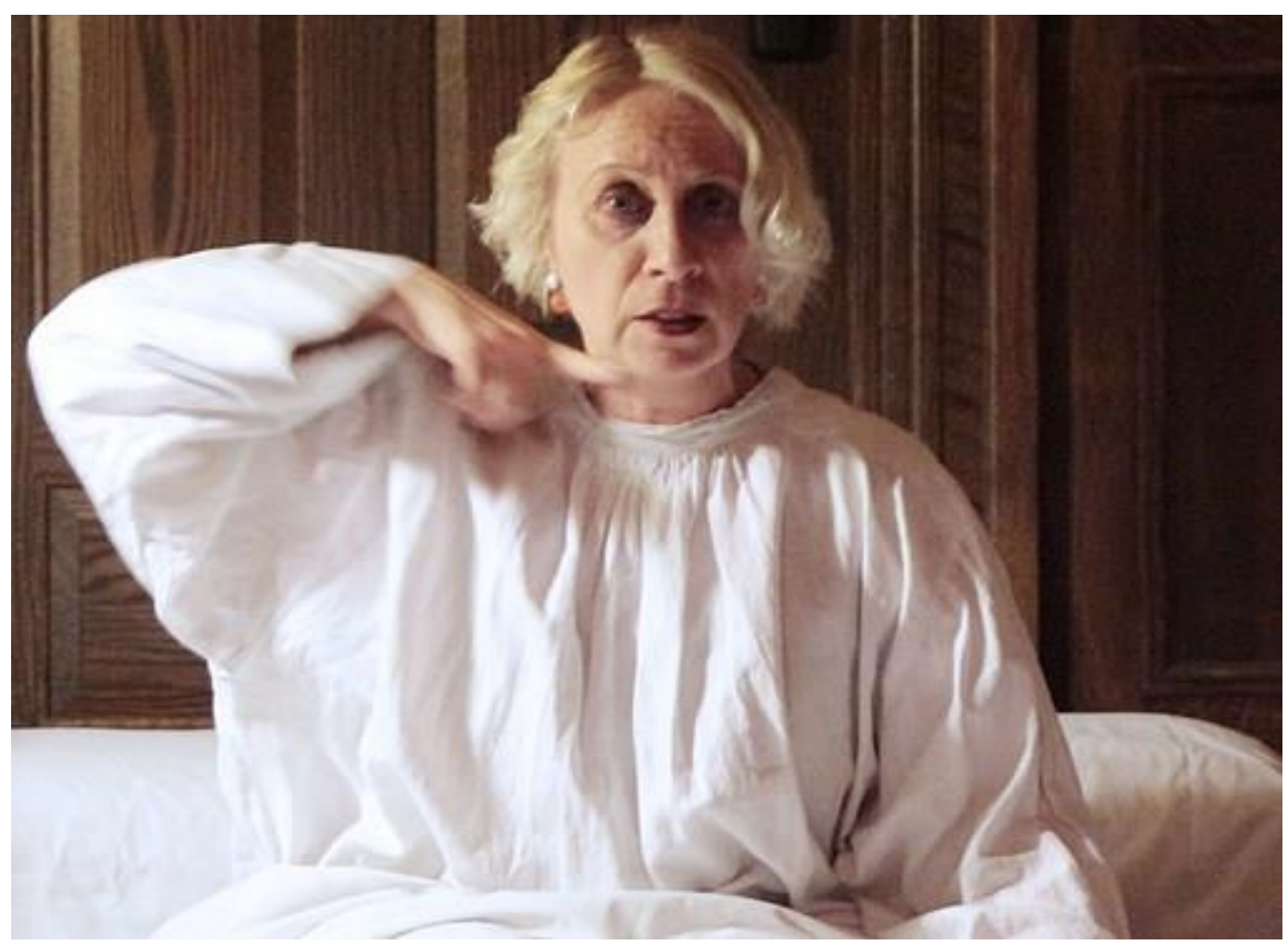

Figure 7. Jacqueline Long as Julia speaks to the audience in Part II. (Photo courtesy of the Department of Fine and Performing Arts, Loyola University Chicago.)

One explicit but oddly maladroit reference to Classical mythology Fefu makes gave me an important opening. She claims that women, unlike men, cannot be at ease with one another "like Orpheus" (15). Neither the circumstances nor the emotion fit. Orpheus is not associating with his own sex and he is not uncomfortable: he is failing to recover his wife from death because he looks back at her too soon, before they have exited the Underworld. ${ }^{24}$ When an ancient Greek or Roman Alexandrian poet mangled a myth so much, he often was combining it obliquely with a second one. The "Mexican joke" Fornés turned into Fefu's game of shooting her husband Philip supplies the missing connections: "There are two Mexicans speaking at a bullfight. One says to the other, 'She is pretty, that one over there.' The other one says, 'Which one?' So the first one takes his rifle and shoots her. He says, 'That one, the one that falls.", 25

Orpheus, like the Mexican, exercises agency. Whereas the Mexican singles out his object casually, Orpheus, like Fefu, targets his spouse. His looking, like her shooting, mingles fatality and desire, beyond intentionality. ${ }^{26}$ Fornés complicated Fefu's status as 
agent with the idea Philip has told her "one day he'll put real bullets in the gun" (13). When she shoots him with blanks he falls unwounded. Orpheus's gaze is reflected rather when Fefu looks in Julia's eyes and sees death (59). This scene was agony for me to play as Julia. When Bren as Fefu looked in my eyes, the allusion to Orpheus made her not only Fornés's Mexican with the gun, but also Julia's and my second self. Her need for Philip renewed my ache for Julia's lost love-life (52). Other details, too, identify the characters $(17,34)$. Orpheus brought them into focus for me and returned in the scene with Fefu to silence his Eurydice, Fornés's Julia, and me as actor. How could I communicate such dire recognition? When Fefu shoots the rabbit, Julia, unhit, collapses bleeding, inverting Philip's male nonchalance again. Fefu's gun blows a female world apart.

Another classical resonance may be signaled by the bizarre gesture Fornés's stage directions bid Julia make in Fefu's hallucination: "Julia enters in slow motion, walking. She goes to the coffee table, gets the sugar bowl, lifts it in Fefu's direction, takes the cover off, puts it back on and walks to the kitchen" (55). The oddness of Julia's flourish calls attention to the hallucination as such. And Julia insists, "Hallucinations are real" (44). A Classicist cannot but think of Pandora's jar. ${ }^{27}$ Economy of symbolism in Hesiod's two versions of the story equates the jar with women's bodies, for men both burden and necessary bearer of the next generation. Julia's lidded sugar-bowl, too, may signal the release of destructive forces, but also women themselves. Fornés's ending asks whether Fefu and her friends still possess hope.

It pushes Fornés's text to insist she intended both momentary references, one nonverbal in performance, to invoke Classical archetypes. Yet a literary past repels repression: Orpheus and Pandora, examined, bring forward themes of agency, mortality, and the role of the female that are clearly integral to Fornés's project in Fefu. In working up the whole script for performance we found myriad details and dimensions belly forth with similar fecundity. The philologist has intellectual time (or scholarly articles) in which to explicate details. The dramaturge has actors, who must charge moments with knowledge and spark them into understanding and feeling in real time. Alone in Julia's hallucinations, I locked eyes with my audiences: "feel the threats that beat me! Shelter Fefu! Understand!" Although the distinctness of the past I study, like the integrity of a dramatic fiction, demands anachronism be eschewed, our collaboration realizing Fornés's script 
demonstrated how dynamically a collective imagination may test the possibilities of ostensibly static sources and form a valid image of the world they reflect. ${ }^{28}$ Conversely, the embodied experience of performing $F e f u$ is a valuable reminder for a Classicist that the past we conjure in scholarly imagination was embodied in its own reality, too. I strive to challenge my students with the fact that our texts bespeak a world.

In Classical antiquity, drama carried imaginations across gendered boundaries to test alternative possibilities. Men were the authors, performers, and audience. Yet a chorus could sing that, by avenging her husband's desertion, Medea would redeem women's lives from obloquy generally. ${ }^{29}$ In many plays women's existence proves a strong instance of tragic constraints on human worth: Medea breaks through her gender, her marriage, her motherhood, and her humanity in a terrifying transcendence. ${ }^{30}$ Fefu's hampered agency, embodied in her gun, champs at the same curbs. Broken Julia is Fefu's sad counterpart, Ismene to Antigone. Themes and character-dynamics shared by Fornés with the classics illustrate continuity of dramatic interest.

Aristophanes joked in his literary-critical Thesmophoriazusae with the idea that male poets won insight into female characters by putting on female costume. His metafiction declares, humorously, fictions around theatrical performance could even surmount barriers of gender. ${ }^{31}$ Through the play's main action ludicrous cross-dressing modulates into meditation on more constructive dramatizations of women in Euripidean tragedy: while in Classical comedy the body ultimately asserts itself, a passage through feminization and constraint nevertheless effects genuine change and productive understanding. In a similar way, our passage through Fefu has left the imprint of dynamic collaboration with the words of Fornés's characters. We were "guardians to each other" (53) as we shared our cooking at rehearsals, remembered one another's lines, and unpacked together resonances of Fornés's text with our disciplines. Integrating our perspectives through performance, we brought $F e f u$ into embodied dimensionality, projecting with our selves. The final union of play, players, and audience set the scrim anew. Our project was temporary, but transformative. It strengthens me as a Classicist endeavoring to return reality to past words and imaginations: I and my friends, colleagues and students, live to learn and share. 


\section{Héctor García, Senior Lecturer, Department of Modern Languages and Literatures}

Fefu and Her Friends is a play written by a woman about women and... men are left out! Yes, there are two or three instances where male presences are recognized, but a male figure is never seen. Men remain outside, they are passive and silent. Fefu's husband remains outside the home and never speaks. As the sole male faculty member of this collaborative interdisciplinary project, I have a peculiar and special relationship, not only to the male characters, but to the all-female cast of the play. Month after month as our project expanded and then took shape, I was fortunate enough to witness the glorious transformation of my female companions as they sought to perform their respective female roles. I became, and still am, a privileged member who can enter their female space as a male collaborator.

I was initially torn between different projects brainstormed during our numerous private conversations and the academic presentations we shared with different audiences. As a professor of literature, gender theory, and cultural studies, specifically from the Iberian-Latin@ American landscapes, should I focus solely on the theoretical literary representations borne from Shakespeare's famous phrase, "all the world's a stage" from As You Like It, or better yet, seek inspiration from the Spanish Baroque play, La vida es sueño/Life is a dream written by Pedro Calderón de la Barca? My present research and academic interests in queer theory and cinematic studies led me to ponder how the gaze, and my personal position in this play as a male viewer, could bear interesting fruit.

The range of meaning of the verb "to see" is so vast that a typical thesaurus usually contains a healthy list of many synonyms, among them: to look, glimpse, eye, notice, stare, peek; and to an extreme there is the "voyeur," an individual who takes seeing to visually gratifying heights. While each word involves the act of perception, per se, all have slightly different shades of connotation. For instance, "to peek" suggests a quick glance where the subject is unaware of someone's furtive visual actions. From the long list of possible synonyms, however, "gaze", particularly in psychoanalytic circles, has been singled out for its creative potential in literary discussions and the visual arts. What is it specifically 
about the term "gaze" and its impact on my experience as a male viewer of Fefu's all female spectacle?

A possible explanation may lie in the growing awareness and concern in the twentieth century with the implications of the male gaze and its active role in understanding the function of the visual arts in a society where spatial binaries (viewer/viewed, public/private, subject/object) are being challenged as different concepts of performativity_-performance theory has created new discourses, not only in the social sciences but in cultural and gender studies. My male privilege is, however, fortified; my male gaze strengthens patriarchy. Whether I acknowledge it or not, I too am complicit and Laura Mulvey will not let me forget this! With these associations in mind, one could begin to argue that sight has been relegated to the feminine realm, a sphere very much in place and at home in Fefu. Is this collective female gaze challenging my male gaze?

There must be someone to gaze, and there may be someone to gaze back. During the multiple Fefu performances, the spectator "gave the gaze"; in this case I was one of the spectators, looking at the "female objects" who moved from one room to another while repeating their scenes. The all female cast, in turn, "set themselves at gaze" as they displayed themselves for the audience and performed for each other, all the while pretending there was no audience.

From a more theoretical angle, a gaze can be used to confer meaning upon a piece, whether the gaze emanates from a single viewer or the actors' (re)creation of their performance space. In the first chapter of his book The Order of Things, "Las Meninas," the French philosopher and scholar, Michel Foucault examines the peculiar function of the gaze in the quintessential Spanish Baroque masterpiece by D. Velázquéz, "Las meninas/The Maids of Honor. " 32 In this painting, the spectator who stands directly in front of this large painting (it is more than 100 inches width and height) also becomes the subject of the painting. How is this achieved? The viewer, engulfed by the sheer size and optical effects of the painting, is captured by the gaze of the painter insofar as he/she remains an engaged spectator viewing the painting - the "observer and the observed take part in a ceaseless exchange. No gaze is stable...subject and object, spectator and model reverse their roles into infinity." ${ }^{33}$ The interplay between gazes successfully blurs the boundaries between the more traditional static roles of observer and performer, until it becomes 
difficult to pinpoint who exactly is gazing at whom, and who is the subject of the performance. Here, as in our performance of Fefu, the gaze becomes a mode of interaction between spectator and the work of art. Ultimately, I too became a performer during my multiple appearances at the performances of Fefu.

Within Fefu's performative dimension, I would further argue that this interplay between the initial binary gazes was multiplied as we witnessed and partook in the ambulatory performances within the intimate and closed quarters of Piper Hall. Indeed, a certain power dynamic is inherent within the gaze as a medium, and human subjects as moving images possess an even more commanding presence. Is there a perverse pleasure in looking and not being able to look away? Fefu and her seven, a male spectator (myself) who was transfixed and invited to partake in the transformative synergy of Fefu and Her Friends.

\section{Bren Ortega Murphy, Professor, Women's Studies and Gender Studies, School of Communication}

The ongoing challenge of performance studies is to refuse and supersede this deeply entrenched division of labor, apartheid of knowledges, that plays out inside the academy as the difference between thinking and doing, interpreting and making, conceptualizing and creating. The division of labor between theory and practice, abstraction and embodiment, is an arbitrary and rigged choice and, like all binarisms, is booby-trapped. ${ }^{34}$

Performance studies was developed as a formal academic field in the United States during the mid-twentieth century; emerging almost simultaneously at Northwestern University and New York University. Originally grounded in literary theory, theatre, and anthropology, it is still described as an intersection among those and other fields of study, such as feminist criticism, gender studies, critical race theory, and queer theory. As indicated in the opening quotation, performance studies was and continues to be designed to challenge false dichotomies and to blur boundaries. That said, this perspective is not so diffuse that it cannot reveal moments of truth. Something vital and concrete can be gleaned at the intersection of "thinking and doing, interpreting and making, conceptualizing and 
creating." That is why I chose this lens with which to examine my experience in performing Fefu and Her Friends.

Our intention in performing the play rather than simply studying it or even reading it aloud was to reveal truths to ourselves, both as scholars and women; truths that could not be revealed in any other way. This goal is clearly supported by two core concepts of performance studies. The first is that performance is a vital means of theoretical and pragmatic inquiry, particularly regarding identity and relationship. In other words, we believed that the embodiment and interaction of those characters would yield insight into issues of gender, class, and even race (despite the fact that all of the characters are Caucasian). However, performance presented us with an intriguing dilemma. On the one hand, most of us had come to this project as theatrical amateurs - as scholars rather than theatrical performers. More specifically, we came together as scholars from a variety of academic disciplines and approached the text of the play with different intellectual lenses. We were held together by a commitment to feminist inquiry. Through hours of rehearsal we listened to each other's insights and developed deepening friendships as scholars and as women. In this effort, I was particularly inspired by the work of Performance Studies scholar Dwight Conquergood who wrote "(An) important way of knowing is from the ground level, in the thick of things. This is knowledge that is anchored in practice and circulated within a performance community, but is ephemeral. Donna Haraway locates this homely and vulnerable 'view from a body' in contract to the abstract and authoritative 'view from above,' universal knowledge that pretends to transcend location." ${ }_{35}$

Our primary "performance community" was ourselves: diverse scholars with widely varying acting experience. However, the weight of our inquiry was supposed to be informed by our actual performance to an audience-an audience that had come to experience something worth their while. In other words, there were aesthetic expectations to be met and there was an actual audience to consider. The striving to address these aesthetic demands is congruent with performance theory's concern with the effectiveness of performance. In this case, effective performance was shaped by layers of relationship. In actual performance, we were relating to each other as intellectual colleagues, as friends, and as people who had to remember our lines. We were dependent on each other and changed each other. 
The second core concept of performance studies that I found relevant to our project is that performance pervades almost every aspect of everyday life. One way to use this perspective is as an outside observer who examines how people unknowingly construct meaning for their lives through their own interactions. One example would be how people enact gender without having to give it much thought — an insight that can be traced directly back to Mary Wollstonecraft's eighteenth-century groundbreaking work, A Vindication of the Rights of Woman. Another angle is to examine how people knowingly select or challenge the "scripts" that they have been given by societal norms and expectations. As we referenced in the introduction to our essays, we were intellectually enriched by the writings of Butler and Sedgwick, whose work has been used by many to explain the power of performance in daily life. As Amanda Kemp observed, we used "performance both as a way of knowing and as a way of showing." 36

It is this latter perspective that helped me approach our performance. Giving voice/body to the character of Fefu was challenging. She often says things to provoke a response (which she clearly admits). Indeed, the play opens with her seemingly unprovoked statement "My husband married me to have a constant reminder of how loathsome women are" (7), a comment which triggers a good part of the first act. She seems to know what she's doing. As she says to Cindy, she is sane and very bright but, like many of the others, especially Julia, this consciousness makes life painful since she can perform her role well but sees the discrepancy between a successful performance and an authentic life. Fixing a toilet makes more sense to her than performing as a woman/a wife in her situation. She uses derisive statements about "women" in order to challenge the "eternal feminine," a term made popular in intellectual circles of the 1950s by Simone DeBeauvoir's 1949 The Second Sex. ${ }^{37}$ But she also expresses support and deep affection for her friends. She acknowledges the toll her double vision can take on relationships her own well-being, and she certainly sees the price that Julia has paid. Another problem is that she sees men's strength as "natural" and women's strength as erratic. She is fearful of how women access strength while at the same time, she sees the loss of a woman's mind and spirit as the price of accepting what society considers "natural." She has two intellectual peers, Emma and Julia. Unfortunately, neither can bring her a sense of release. It's not that Emma is insincere, but, rather, that she has found a way to "buy into the script" 
even as she makes revolutionary pronouncements. Julia has found her own dark release from scripts but she is either incapable or unwilling to share her insights in a way that her friends can comprehend.

I learned a number of things from performing the role of Fefu. First, I experienced in a singular way what it is like to be caught between the abstract performance of woman and the specific demands of interacting with particular women. Second, I had to grapple with exactly what Fefu is trying to $d o$. Given her expressed disdain for how she thinks that women enact gender but her inability to change her own script, she is determined to make something real happen, whether it's fixing a toilet or killing a rabbit. Part of her frustration and, indeed her pain come from the fact that she is very good at performance. She is "sane" and "very bright" (13). It seems to me that Fefu was the embodiment of the struggle described by DeBeauvoir, the struggle between immanence and transcendence, between what DeBeavoir saw as a contest between interiority/static self-absorption and extension/action into "the world." ${ }^{38}$ It seems clear that Fefu despises the confinement of women. She explicitly yearns to transcend the traditional "women's world."

However playing Fefu in relationship with the other remarkable women in these performance, revealed to me that immanence is to be valued as well. To be aware of one's own struggles is critical. I, too, am very sane and very bright. I, too, suspect that there is a disconnect between my performance in daily life and who I really am. Like the Bob Fossebased character in the movie All That Jazz, I look at the mirror in the morning and see the tensions between who I am and who I am expected to be, then I splash water on my face and say "it's show time."

Nowhere did I feel the strain of those tensions more explicitly than in my final scene with Julia. It seems to me that of all the characters, Fefu and Julia are the most inexplicable in terms of their intense yearnings, their unexplained obstacles, their unusual strategies of resolution, and their very intimate presence with each other. It is an experience of mystery that I could not have come to without performance.

Performing Fefu elicited many conflicting feelings in me. On the one hand, I felt in control. I moved through my house wearing beautiful clothes. I moved with confidence as though I were "in charge.” On the other hand, playing Fefu made me feel anxious, trapped, and angry. It made me feel resentful of the characters who did not understand me but it 
also made me feel deep love for others' struggles. The final scene with Julia made me frightened and, at the end of scene, I felt drained and profoundly alone.

In terms of teaching, this experience has re-confirmed my belief that performance is a powerful and, perhaps, irreplaceable teacher. I have recently had students in certain classes use performance of play excerpts and children's books as ways to grapple with certain core concepts such as the complexity of communication, ethical struggles, racism, and sexism. As explained earlier in this essay, this approach comes from the performance studies precept that using your entire body to contend with ideas deepens your understanding in a way that mere reading cannot.

In terms of my own growth, the experience of playing Fefu reminded me that being "smart" and "sane" is no protection against fear, confusion, vulnerability and loneliness. It also made me more grateful for all of those women who have struggled and continue to struggle with doubt yet push on with far less societal support than I have. The experience of writing this essay has become another experience. It has made me more aware than ever how interconnected our lives are and how much we benefit from that.

\section{Act III: Crisis and Transformation}

The friends all gather in the parlor to rehearse their parts for the fundraising event. Cecilia asserts "the concern of the educator [is] to teach how to be sensitive to the differences in ourselves as well as outside ourselves...Otherwise the unusual in us will perish" (44). Julia responds, "As I feel I am perishing" (44). The rehearsal begins. Performing excerpts of Educational Dramatics by Emma Sheridan Fry, Emma gives an impassioned call for change in education, quoting "A sense of life universal surges through our life individual." 39 Environment "is our true mate that clamors for our reunion" (47). Once the order of presentation is agreed upon, attention turns to everyday matters such as doing the dishes. This task is interrupted by a water fight. Some of the friends reflect about college days and then leave to look at the stars. Fefu challenges Julia to fight her affliction and show her how to fight. Julia argues she is too weak. A frustrated Fefu picks up the gun she uses in her game with Phillip and goes outside to shoot. She returns with a dead rabbit 
and sees that Julia has apparently suffered a head wound, maybe mortal. The friends gather around Julia in silence.

Just as the play ends with uncertainty about the fate of Julia and the future of the friends' lives, so having completed our performance project, the members of the Gender Research Seminar faced the question "what next?" Writing our personal essays was a first step. From these essays we hoped to define our understanding and practice of interdisciplinarity more fully. We achieved a deeper understanding of gender as affective and performative in our lives and disciplines. Embodied research meant not only gender awareness, but also critical awareness of traditional perceptions of space, affective relationships, and agency. Still in our disciplinary mindsets, we asked "how was this project interdisciplinary?" In post-mortem conversations we joked about how challenging it was to justify the very real time and energy devoted to this project in our annual departmental assessments for salary raises and promotion at our university. The jokes finally led to our aha moment. Performance itself dissolved the boundaries of separate disciplines and enabled us to learn new ways to work together. It is working around and between traditional disciplinary boundaries that creates interdisciplinarity.

In fact, through the affective analysis that performance allows, we came to see the ending of the play as Fornés's project to stage interconnectedness, in our terms, to stage interdisciplinarity. Boundaries dissolved between exterior and interior with Julia's wound inside from the gunshot outside, and as friends we circled around in an effort to understand, in a silent, shared moment of presence. By living through that process with one another in performance, we increased moments of presence and connectedness in our lives. Among our most treasured discoveries in this project were the emotional dimensions we unlocked across our personal and professional relationships. Already close colleagues, many of us friends, in rehearsal and performance we encountered each other as a layered mélange of colleague-scholar-friend - opening up emotional, affective connections that have enriched our individual teaching and scholarship exponentially, as well as our further collaborative projects with one another, many using performance methods. Even our relationship to authorities in the university has been impacted, since cast members have moved into administrative positions as directors of programs, associate deans, and deans of schools since we performed. 
Performing Fefu was a communal endeavor, involving activities that lie outside the parameters of most established fields. Because of this, we were allowed to see ourselves, particularly ourselves in relation to our genders and our bodies in spaces and communities, in new ways. We positioned ourselves outside the disciplinary norms of academia, revealing new approaches to knowledge creation. Performing eight female characters engaged in pursuits so familiar with ours, framed and set apart our everyday activities, from washing dishes to planning events, and allowed us new perspective on multiple aspects of our own identities and behaviors. Applying the terms of German playwright and theorist Bertolt Brecht, through our performance practice, the familiar was made strange.We were able to see ourselves, as individuals and as a community of scholars and friends, with fresh eyes. This fresh perspective was enhanced by, in fact predicated on, our being mostly nonperformers. As a group we did not bring many specific expectations to the pursuit. Not only did performing our familiar activities provide enlightening distance on those aspects of our lives, but we approached performance without the sense of normalcy and attendant assumptions that seasoned performers would bring to a project. We were therefore less biased in our approaches and more open to new experienced-based knowledge. We made the performance strange, discovering and investigating stages of the process as we went. In the freshness of this new methodology, we were able to learn not only about our lives and larger interdisciplinary studies, but also a great deal about performance as an unique form of research practice.

Since Fefu, the group has initiated several new teaching and research projects using performance methods. These include a new course entitled "Community as Story” in which students create and perform original stories for children with diverse subjects; revision to the WSGS Methodologies and Capstone sequence to include performance methodologies as a means of disseminating research and oral histories; revisions to Introductory Acting classes to include the performance of gender, and revised pedagogies for playing queer characters; added performance dimensions to the Women in Greek Tragedy course; engagements with historians using a performance method entitled "Reacting to the Past;" as well as initial conversations about collaborations between Theatre and Social Work in using actors as "mock clients." In addition, this project has led to the use of performance as research with professional and student organizations, including the Center for Urban 
Learning and Research, National Women's Studies Association, International Theatre and Pedagogy of the Oppressed, and Feminist Forum, to name a few. Members of the Seminar have contributed to dramaturgy and talkbacks on theatre productions of The Trojan Women, FML, The House of Bernarda Alba, and A Doll's House. In 2014-2015 the Seminar was awarded a major grant from the College of Arts and Sciences' Center for Interdisciplinary Thinking for "Performance, Space, and Affect," in which we combined new research in yoga and performance to create ensemble movement for excerpts of an original adaptation of Charlotte Perkins Gillman's "The Yellow Wallpaper." This year we are pursuing funding for a new interdisciplinary program entitled "Living History/Performing Change," which gathers projects combining research in performance and history under one interdisciplinary umbrella to promote diversity and inclusion in programming and increase community engagement to advance Loyola's social justice mission.

The administration of the WSGS program has taken a new direction as well. For a decade the program has invested creativity and energy in trying to find a way to become a department, as recognition of the equal status and resources that the program deserves. Our performance project led us to reject this effort at assimilation into a disciplinary structure. We are now moving to strengthen our relationships across disciplinary boundaries and through collaboration as an expression of our interdisciplinary claims.

A performance approach to research, teaching, and service has enabled us to define ourselves and our work according to our own creative purposes rather than allowing others to define us. The result is a transformation of energy for achieving goals that are both satisfying to us and socially useful. We hope that this detailed exploration of our experience will encourage others to think of a performance project as a catalyst for opening new approaches to their life and work.

${ }^{1}$ María Irene Fornés, Fefu and Her Friends (New York: PAJ Publications, 1978).

${ }^{2}$ Northwestern University Wallace Theater, 1993; North Lakeside Cultural Center, 1999.

${ }^{3}$ Though all the participants were familiar with literature on some or all of the theoretical frameworks these are the essays we read together. Jennifer Purvis, "Queer," in 
Rethinking Women's and Gender Studies, ed. Catherine M. Orr, Ann Braithwaite, Diane Lichtenstein (New York: Routledge, 2012),189-205. Paula M. Niedenthal, Lawrence W. Barsalou, Piotr Winkielman, Silvia Krauth-Gruber, and François Ric, "Embodiment in Attitudes, Social Perception, and Emotion," Personality and Social Psychology Review 9, no. 3 (2005):184. Elinor Fuchs, "Fefu and Her Friends: The View from the Stone," in The Theater of María Irene Fornés, ed. Marc Robinson (Baltimore: Johns Hopkins University Press, 1999). Judith Butler, Gender Trouble: Feminism and the Subversion of Identity, (New York, Routledge, 1990).

${ }^{4}$ Butler, Gender Trouble.

${ }^{5}$ Eve K. Sedgwick, "Introduction," in Touching Feeling: Affect, Pedagogy and Performativity (Durham, NC: Duke University Press, 2003), 1.

${ }^{6}$ Sue-Ellen Case, Feminism and Theatre (New York: Routledge, 1988).

${ }^{7}$ A few of many sources for feminism and theatre: Gayle Austin, Feminist Theories for Dramatic Criticism (Ann Arbor: University of Michigan Press, 1990); SueEllen Case, "Classic Drag: The Greek Creation of Female Parts," Theatre Journal 37, no. 3 (Oct. 1985): 317-27; Jill Dolan, The Feminist Spectator as Critic (Ann Arbor; University of Michigan Press, 1991); Sue-Ellen Case, Feminism and Theatre (1988; repr., New York: Palgrave MacMillan, 2008).

${ }^{8}$ Ann Shanahan, 'Un-blocking Hedda and Medea through Feminist 'Play' with Traditional Staging Forms," Theatre Topics 21, no. 1 (March 2011): 1.

${ }^{9}$ Marc Robinson, "The Summer in Gossensass: Fornés and Criticism," in The Theater of María Irene Fornés, ed. Marc Robinson (Baltimore: Johns Hopkins University Press, 1999), 109.

${ }^{10}$ Elinor Fuchs, "Fefu and Her Friends: The View from the Stone," in The Theater of María Irene Fornés, ed. Marc Robinson (Baltimore: Johns Hopkins University Press, 1999), 89.

${ }^{11}$ Ibid.

${ }^{12}$ Ibid

${ }^{13}$ Ann Shanahan, "Playing House: Staging Experiments about Women in Domestic Space," Theatre Topics 23, no. 2 (September 2013): 129-144. A few lines of this previously published essay are reprinted here in Shanahan's essay and in the introduction to this essay in significantly revised form.

${ }^{14}$ bell hooks, Teaching to Transgress: Education as the Practice of Freedom (New York: Routledge, 1994).

${ }^{15}$ Butler, Gender Trouble. 
${ }^{16}$ Amy K. Levin, Questions for a New Century: Women's Studies and Integrative Learning, A Report to the National Women's Studies Association, (College Park, MD: NWSA, 2007), 12.

${ }^{17}$ Ann Pettitt, Walking to Greenham: How the Peace Camp Began and the Cold War Ended (South Glamorgan, Wales: Honno Publishers, 2006), 1.

${ }^{18}$ Sasha Roseneil, Disarming Patriarchy: Feminism and Political Action at Greenham (Buckingham, UK: Open University Press, 1995), 1.

19 Joan Wallach Scott, "Gender: A Useful Category of Historical Analysis," in Gender and the Politics of History (New York: Columbia University Press, 1988), 48.

${ }^{20}$ Butler, Gender Trouble, 12.

21 Ibid., 15.

${ }^{22}$ Eugenia Delamotte, Gates of Freedom: Voltairine de Cleyre and the Revolution of the Mind (Ann Arbor: University of Michigan Press, 2004), 10-11.

${ }^{23}$ Ibid., 229.

${ }^{24}$ Apollodorus 1.3.2, Verg. G. 4.454-503, Ov. Met. 10.1-77, etc.

${ }^{25}$ María Irene Fornés and Robb Creese, "I Write These Messages that Come,"” The Drama Review 21, no. 4 (Dec. 1977): 30.

26 “It suits our relationship ... the game, I mean. If I didn't shoot him with blanks, I might shoot him for real" (13); "I need his touch. I need his kiss. I need the person he is. I can't give him up" (59). In a similar spirit, Orpheus refuses to accept his spouse's death.

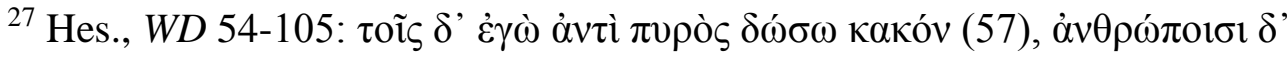

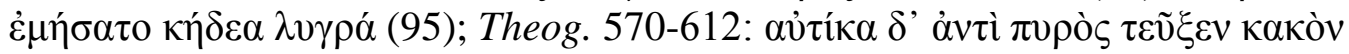
$\dot{\alpha} v \theta \rho \omega ́ \pi 0 ı \sigma ı v ~(570)$.

${ }^{28}$ Feminist scholarship contributes to Classical Studies a consciousness of theory, e.g., Barbara F. McManus, Classics and Feminism: Gendering the Classics (New York: Twayne Publishers, 1997); Nancy Sorkin Rabinowitz and Amy Richlin, eds., Feminist Theory and the Classics (New York: Routledge, 1993).

${ }^{29}$ Eur. Med. 853-55, cf. 424-29.

${ }^{30}$ Sophocles especially: Oedipus, Philoctetes; but gendered juxtapositions also highlight the theme, e.g., Ajax and Tecmessa [v. Kirk Ormand, Exchange and the Maiden: Marriage in Sophoclean Tragedy (Austin: University of Texas Press, 1999); Clytaemnestra's victims Agamemnon and Cassandra, Phaedra and Hippolytus. Thus 
tragedies "used women to think with," cf. Helene Foley, "The Conception of Women in Athenian Drama," in Reflections of Women in Antiquity, ed. Helene Foley (New York: Gordon \& Breach Science Publishers, 1981), 126-167; and Helen Foley, Female Acts in Greek Tragedy (Princeton: Princeton University Press, 2002).

${ }^{31}$ Ar. Thesmo. 148-74.

${ }^{32}$ Michel Foucault, "Las Meninas," in The Order of Things: An Archaeology of the Human Sciences (New York: Vintage Books, 1970), 3-16.

${ }^{33}$ Ibid., 5.

${ }^{34}$ Dwight Conquergood, "Performance Studies: Interventions and Radical Research," The Drama Review 46, no. 2 (summer 2002): 153.

${ }^{35}$ Ibid., 196.

${ }^{36}$ Amanda Kemp, "The Black Body in Question," in The Ends of Performance ed. Peggy Phelan and Jill Lane (New York: New York University Press, 1998), 116.

${ }^{37}$ Simone DeBeauvoir, The Second Sex, trans. H.M. Parshley (New York: Random House, 1989), 180.

${ }^{38}$ Ibid., 679-732.

${ }^{39}$ E.S. Fry, Educational Dramatics: A Handbook on the Educational Player Method (New York, Moffat, Yard and Co., 1917). 